4

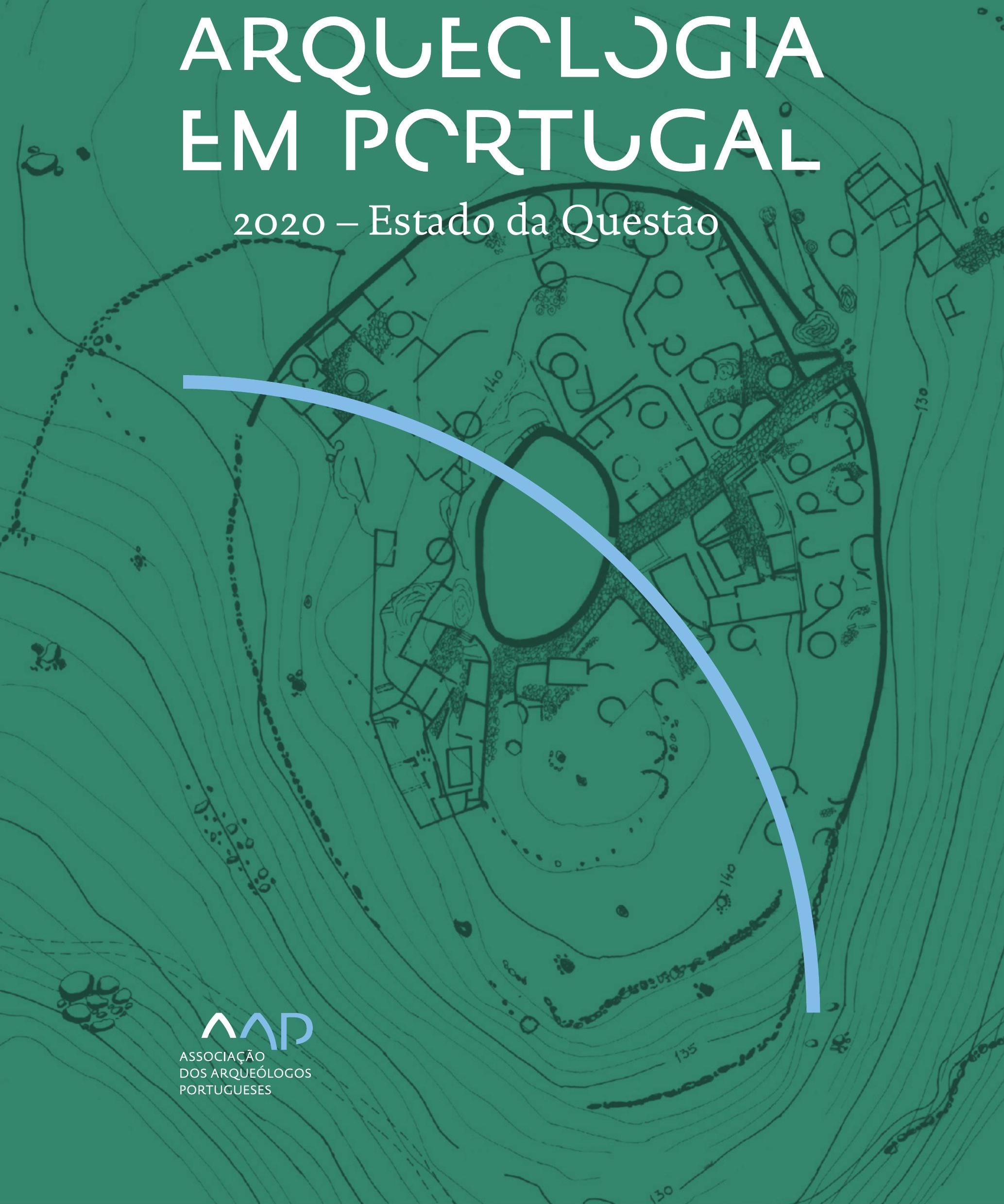


Coordenação editorial: José Morais Arnaud, César Neves e Andrea Martins Design gráfico: Flatland Design

AAP - ISBN: 978-972-9451-89-8

CITCEM - ISBN: 978-989-8970-25-1

Associação dos Arqueólogos Portugueses e CITCEM

Lisboa, 2020

O conteúdo dos artigos é da inteira responsabilidade dos autores. Sendo assim a Associação dos Arqueólogos Portugueses declina qualquer responsabilidade por eventuais equívocos ou questões de ordem ética e legal.

Desenho de capa:

Planta do castro de Monte Mozinho (Museu Municipal de Penafiel).

\section{$\hat{\wedge} \mathrm{P}$}

DOS ARQUEÓLOGOS PORTUGUESES

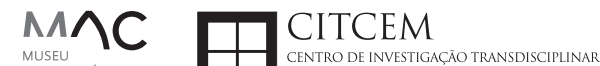
MUSEU
ARQUELLÓGICO
DO CARMO
U.PORTO

FLUP FACULDADE DE LETRAS
UNIVERSIDADE DO PORTO

Apoio

EC para a Ciência 


\section{Índice}

15 Prefácio

José Morais Arnaud

\section{Historiografia e Teoria}

17 Território, comunidade, memória e emoção: a contribuição da história da arqueologia (algumas primeiras e breves reflexões)

Ana Cristina Martins

25 Como descolonizar a arqueologia portuguesa?

Rui Gomes Coelho

41 Arqueologia e Modernidade: uma revisitação pessoal e breve de alguns aspetos da obra homónima de Julian Thomas de 2004

Vítor Oliveira Jorge

57 Dados para a História das Mulheres na Arqueologia portuguesa, dos finais do século XIX aos inícios do século XX: números, nomes e tabelas

Filipa Dimas / Mariana Diniz

73 Retractos da arqueologia portuguesa na imprensa: (in)visibilidades no feminino

Catarina Costeira / Elsa Luís

85 Arqueologia e Arqueólogos no Norte de Portugal Jacinta Bugalhão

101 Vieira Guimarães (1864-1939) e a arqueologia em Tomar: uma abordagem sobre o território e as gentes

João Amendoeira Peixoto / Ana Cristina Martins

115 Os memoráveis? A arqueologia algarvia na imprensa nacional e regional na presente centúria (2001-2019): características, visões do(s) passado(s) e a arqueologia

enquanto marca

Frederico Agosto / João Silva

129 A Evolução da Arqueologia Urbana e a Valorização Patrimonial no Barlavento Algarvio: Os casos de Portimão e Silves

Artur Mateus / Diogo Varandas / Rafael Boavida

\section{Gestão, Valorização e Salvaguarda do Património}

145 O Caderno Reivindicativo e as condições de trabalho em Arqueologia Miguel Rocha / Liliana Matias Carvalho / Regis Barbosa / Mauro Correia / Sara Simões / Jacinta Bugalhão / Sara Brito / Liliana Veríssimo Carvalho / Richard Peace / Pedro Peça / Cézer Santos

155 Os Estudos de Impacte Patrimonial como elemento para uma estratégia sustentável de minimização de impactes no âmbito de reconversões agrícolas Tiago do Pereiro

165 Salvaguarda de Património arqueológico em operações florestais: gestão e sensibilização Filipa Bragança / Gertrudes Zambujo / Sandra Lourenço / Belém Paiva / Carlos Banha / Frederico Tatá Regala / Helena Moura / Jacinta Bugalhão / João Marques / José Correia / Pedro Faria / Samuel Melro

179 Os valores do Património: uma investigação sobre os Sítios Pré-históricos de Arte Rupestre do Vale do Rio Côa e de Siega Verde José Paulo Francisco 
189 Conjugando recursos arqueológicos e naturais para potenciar as visitas ao Geoparque Litoral de Viana do Castelo (Noroeste de Portugal)

Hugo A. Sampaio / Ana M.S. Bettencourt / Susana Marinho / Ricardo Carvalhido

203 Áreas de Potencial Arqueológico na Região do Médio Tejo: Modelo Espacial Preditivo Rita Ferreira Anastácio / Ana Filipa Martins / Luiz Oosterbeek

223 Património Arqueológico e Gestão Territorial: O contributo da Arqueologia para a revisão do PDM de Avis

Ana Cristina Ribeiro

237 A coleção arqueológica do extinto Museu Municipal do Porto - Origens, Percursos e Estudos

Sónia Couto

251 Valpaços - uma nova carta arqueológica

Pedro Pereira / Maria de Fátima Casares Machado

263 Arqueologia na Cidade de Peniche

Adriano Constantino / Luís Rendeiro

273 Arqueologia Urbana: a cidade de Lagos como caso de Estudo Cátia Neto

285 Estratégias de promoção do património cultural subaquático nos Açores. O caso da ilha do Faial

José Luís Neto / José Bettencourt / Luís Borges / Pedro Parreira

297 Carta Arqueológica da Cidade Velha: Uma primeira abordagem

Jaylson Monteiro / Nireide Tavares / Sara da Veiga / Claudino Ramos / Edson Brito /

Carlos Carvalho / Francisco Moreira / Adalberto Tavares

311 Antropologia Virtual: novas metodologias para a análise morfológica e funcional Ricardo Miguel Godinho / Célia Gonçalves

\section{Didáctica da Arqueologia}

327 Como os projetos de Arqueologia podem contribuir para uma comunidade culturalmente mais consciente Alexandra Figueiredo / Claúdio Monteiro / Adolfo Silveira / Ricardo Lopes

337 Educação Patrimonial - Um cidadão esclarecido é um cidadão ativo! Ana Paula Almeida

351 A aproximação da Arqueologia à sala de aula: um caso de estudo no $3^{\circ}$ ciclo do Ensino Básico Luís Serrão Gil

363 Arqueologia 3.o - Pensar e comunicar a Arqueologia para um futuro sustentável Mónica Rolo

377 “Conversa de Arqueólogos" - Divulgar a Arqueologia em tempos de Pandemia Diogo Teixeira Dias

389 Escola Profissional de Arqueologia: desafios e oportunidades Susana Nunes / Dulcineia Pinto / Júlia Silva / Ana Mascarenhas

399 Os Museus de Arqueologia e os Jovens: a oferta educativa para o público adolescente Beatriz Correia Barata / Leonor Medeiros

411 O museu universitário como mediador entre a ciência e a sociedade: o exemplo da secção de arqueologia no Museu de História Natural e da Ciência da Universidade do Porto (MHNC-UP)

Rita Gaspar 
421 Museu de Lanifícios: Real Fábrica de Panos. Atividades no âmbito da Arqueologia Beatriz Correia Barata / Rita Salvado

427 Arqueologia Pública e o caso da localidade da Mata (Torres Novas) Cláudia Manso / Ana Rita Ferreira / Cristiana Ferreira / Vanessa Cardoso Antunes

431 Do sítio arqueológico ao museu: um percurso (também) didático Lídia Fernandes

447 Estão todos convidados para a Festa! E para dançar também... O projecto do Serviço Educativo do Museu Arqueológico do Carmo na $5^{\underline{a}}$ Edição da Festa da Arqueologia Rita Pires dos Santos

459 O “Clã de Carenque”, um projeto didático de arqueologia Eduardo Gonzalez Rocha

469 Mediação cultural: peixe que puxa carroça nas Ruínas Romanas de Troia Inês Vaz Pinto / Ana Patrícia Magalhães / Patrícia Brum / Filipa Santos

481 Didática Arqueológica, experiências do Projeto Mértola Vila Museu Maria de Fátima Palma / Clara Rodrigues / Susana Gómez / Lígia Rafael

\section{Arte Rupestre}

497 Os inventários de arte rupestre em Portugal Mila Simões de Abreu

513 O projeto FIRST-ART - conservação, documentação e gestão das primeiras manifestações de arte rupestre no Sudoeste da Península Ibérica: as grutas do Escoural e Maltravieso Sara Garcês / Hipólito Collado / José Julio García Arranz / Luiz Oosterbeek / António Carlos Silva / Pierluigi Rosina / Hugo Gomes / Anabela Borralheiro Pereira / George Nash / Esmeralda Gomes / Nelson Almeida / Carlos Carpetudo

523 Trabalhos de documentação de arte paleolítica realizados no âmbito do projeto PalæoCôa André Tomás Santos / António Fernando Barbosa / Luís Luís / Marcelo Silvestre / Thierry Aubry

537 Imagens fantasmagóricas, silhuetas elusivas: as figuras humanas na arte do Paleolítico Superior da região do Côa Mário Reis

$55^{1}$ Os motivos zoomórficos representados nas placas de tear de Vila Nova de São Pedro (Azambuja, Portugal) Andrea Martins / César Neves / José M. Arnaud / Mariana Diniz

571 Arte Rupestre do Monte de Góios (Lanhelas, Caminha). Síntese dos resultados dos trabalhos efectuados em 2007-2009 Mário Varela Gomes

599 Gravuras rupestres de barquiformes no Monte de S. Romão, Guimarães, Noroeste de Portugal Daniela Cardoso

613 Círculos segmentados gravados na Bacia do Rio Lima (Noroeste de Portugal): contributos para o seu estudo Diogo Marinho / Ana M.S. Bettencourt / Hugo Aluai Sampaio

631 Equídeos gravados no curso inferior do Rio Mouro, Monção (NW Portugal). Análise preliminar Coutinho, L.M. / Bettencourt, A.M.S / Sampaio, Hugo A.S

645 Paletas na Arte Rupestre do Noroeste de Portugal. Inventário preliminar Bruna Sousa Afonso / Ana M. S. Bettencourt / Hugo A. Sampaio 


\section{Pré-História}

661 O projeto Miño/Minho: balanço de quatro anos de trabalhos arqueológicos Sérgio Monteiro-Rodrigues / João Pedro Cunha-Ribeiro / Eduardo Méndez-Quintas / Carlos Ferreira / Pedro Xavier / José Meireles / Alberto Gomes / Manuel Santonja / Alfredo Pérez-González

677 A ocupação paleolítica da margem esquerda do Baixo Minho: a indústria lítica do sítio de Pedreiras 2 (Monção, Portugal) e a sua integração no contexto regional Carlos Ferreira / João Pedro Cunha-Ribeiro / Sérgio Monteiro-Rodrigues / Eduardo Méndez-Quintas / Pedro Xavier / José Meireles / Alberto Gomes / Manuel Santonja / Alfredo Pérez-González

693 O sítio acheulense do Plistocénico médio da Gruta da Aroeira Joan Daura / Montserrat Sanz / Filipa Rodrigues / Pedro Souto / João Zilhão

703 As sociedades neandertais no Barlavento algarvio: modelos preditivos com recurso aos SIG

Daniela Maio

715 A utilização de quartzo durante o Paleolítico Superior no território dos vales dos rios Vouga e Côa

Cristina Gameiro / Thierry Aubry / Bárbara Costa / Sérgio Gomes / Luís Luís / Carmen Manzano / André Tomás Santos

733 Uma perspetiva diacrónica da ocupação do concheiro do Cabeço da Amoreira (Muge, Portugal) a partir da tecnologia lítica Joana Belmiro / João Cascalheira / Célia Gonçalves

745 Novos dados sobre a Pré-história Antiga no concelho de Palmela. A intervenção arqueológica no sítio do Poceirão I

Michelle Teixeira Santos

757 Problemas em torno de Datas Absolutas Pré-Históricas no Norte do Alentejo Jorge de Oliveira

771 Povoamento pré-histórico nas áreas montanhosas do NO de Portugal: o Abrigo 1 de Vale de Cerdeira Pedro Xavier / José Meireles / Carlos Alves

783 Apreciação do povoamento do Neolítico Inicial na Baixa Bacia do Douro. A Lavra I (Serra da Aboboreira) como caso de estudo Maria de Jesus Sanches

797 O Processo de Neolitização na Plataforma do Mondego: os dados do Sector C do Outeiro dos Castelos de Beijós (Carregal do Sal)

João Carlos de Senna-Martinez / José Manuel Quintã Ventura / Andreia Carvalho / Cíntia Maurício

823 Novos trabalhos na Lapa da Bugalheira (Almonda, Torres Novas) Filipa Rodrigues / Pedro Souto / Artur Ferreira / Alexandre Varanda / Luís Gomes / Helena Gomes / João Zilhão

837 A pedra polida e afeiçoada do sítio do Neolítico médio da Moita do Ourives (Benavente, Portugal)

César Neves

857 Casal do Outeiro (Encarnação, Mafra): novos contributos para o conhecimento do povoamento do Neolítico final na Península de Lisboa.

Cátia Delicado / Carlos Maneira e Costa / Marta Miranda / Ana Catarina Sousa

873 Stresse infantil, morbilidade e mortalidade no sítio arqueológico do Neolítico Final/ Calcolítico ( $4^{\circ}$ e $3^{\circ}$ milénio a.C.) do Monte do Carrascal 2 (Ferreira do Alentejo, Beja) Liliana Matias de Carvalho / Sofia N. Wasterlain 
885 Come together: O Conjunto Megalítico das Motas (Monção, Viana do Castelo) e as expressões Campaniformes do Alto Minho Ana Catarina Basílio / Rui Ramos

899 Trabalhos arqueológicos no sítio Calcolítico da Pedreira do Poio Carla Magalhães / João Muralha / Mário Reis / António Batarda Fernandes

913 O sítio arqueológico de Castanheiro do Vento. Da arquitectura do sítio à arquitectura de um território João Muralha Cardoso

925 Estudo zooarqueológico das faunas do Calcolítico final de Vila Nova de São Pedro (Azambuja, Portugal): Campanhas de 2017 e 2018 Cleia Detry / Ana Catarina Francisco / Mariana Diniz / Andrea Martins / César Neves / José Morais Arnaud

943 As faunas depositadas no Museu Arqueológico do Carmo provenientes de Vila Nova de São Pedro (Azambuja): as campanhas de 1937 a 1967 Ana Catarina Francisco / Cleia Detry / César Neves / Andrea Martins / Mariana Diniz / José Morais Arnaud

959 Análise funcional de material lítico em sílex do castro de Vila Nova de S. Pedro (Azambuja, Portugal): uma primeira abordagem Rafael Lima

971 O recinto da Folha do Ouro 1 (Serpa) no contexto dos recintos de fossos calcolíticos alentejanos

António Carlos Valera / Tiago do Pereiro / Pedro Valério / António M. Monge Soares

\section{Proto-História}

987 Produção de sal marinho na Idade do Bronze do noroeste Português. Alguns dados para uma reflexão

Ana M. S. Bettencourt / Sara Luz / Nuno Oliveira / Pedro P. Simões / Maria Isabel C. Alves / Emílio Abad-Vidal

1001 A estátua-menir do Pedrão ou de São Bartolomeu do Mar (Esposende, noroeste de Portugal) no contexto arqueológico da fachada costeira de entre os rios Neiva e Cávado Ana M. S. Bettencourt / Manuel Santos-Estévez / Pedro Pimenta Simões / Luís Gonçalves

1015 O Castro do Muro (Vandoma/Baltar, Paredes) - notas para uma biografia de ocupação da Idade do Bronze à Idade Média

Maria Antónia D. Silva / Ana M. S. Bettencourt / António Manuel S. P. Silva / Natália Félix

1031 Do Bronze Final à Idade Média - continuidades e hiatos na ocupação de Povoados em Oliveira de Azeméis João Tiago Tavares / Adriaan de Man

1041 As faunas do final da Idade do Bronze no Sul de Portugal: leituras desde o Outeiro do Circo (Beja)

Nelson J. Almeida / Íris Dias / Cleia Detry / Eduardo Porfírio / Miguel Serra

1055 A Espada do Monte das Oliveiras (Serpa) - uma arma do Bronze Pleno do Sudoeste Rui M. G. Monge Soares / Pedro Valério / Mariana Nabais / António M. Monge Soares

1065 São Julião da Branca (Albergaria-a-Velha) - Investigação e valorização de um povoado do Bronze Final

António Manuel S. P. Silva / Paulo A. P. Lemos / Sara Almeida e Silva / Edite Martins de Sá

1083 Do castro de S. João ao Mosteiro de Santa Clara: notícia de uma intervenção arqueológica, em Vila do Conde Rui Pinheiro 
1095 O castro de Ovil (Espinho), um quarto de século de investigação - resultados e questões em aberto

Jorge Fernando Salvador / António Manuel S. P. Silva

1111 O Castro de Salreu (Estarreja), um povoado proto-histórico no litoral do Entre Douro e Vouga

Sara Almeida e Silva / António Manuel S. P. Silva / Paulo A. P. Lemos / Edite Martins de Sá

1127 Castro de Nossa Senhora das Necessidades (Sernancelhe): uma primeira análise artefactual Telma Susana O. Ribeiro

${ }_{1141}$ A cividade de Bagunte. O estado atual da investigação Pedro Brochado de Almeida

1153 Zoomorfos na cerâmica da Idade do Ferro no NW Peninsular: inventário, cronologias e significado Nuno Oliveira / Cristina Seoane

1163 Vasos gregos em Portugal: diferentes maneiras de contar a história do intercâmbio cultural na Idade do Ferro

Daniela Ferreira

1175 Os exotica da necrópole da Idade do Ferro do Olival do Senhor dos Mártires (Alcácer do Sal) no seu contexto regional

Francisco B. Gomes

\section{Antiguidade Clássica e Tardia}

1191 O uso de madeira como combustível no sítio da Quinta de Crestelos (Baixo Sabor): da Idade do Ferro à Romanização Filipe Vaz / João Tereso / Sérgio Simões Pereira / José Sastre / Javier Larrazabal Galarza / Susana Cosme / José António Pereira / Israel Espi

1207 Cultivos de Época Romana no Baixo Sabor: continuidade em tempos de mudança? João Pedro Tereso / Sérgio Simões Pereira / Filipe Santos / Luís Seabra / Filipe Vaz

1221 A casa romana na Hispânia: aplicação dos modelos itálicos nas províncias ibéricas Fernanda Magalhães / Diego Machado / Manuela Martins

1235 As pinturas murais romanas da Rua General Sousa Machado, n. ${ }^{5}$ 1, Chaves José Carvalho

1243 Trás do Castelo (Vale de Mir, Pegarinhos, Alijó) - Uma exploração agrícola romana do Douro

Tony Silvino / Pedro Pereira

1255 A sequência de ocupação no quadrante sudeste de Bracara Augusta: as transformações de uma unidade doméstica Lara Fernandes / Manuela Martins

1263 Os Mosaicos com decoração geométrica e geométrico-vegetalista dos sítios arqueológicos da área do Conuentus Bracaraugustanus. Novas abordagens quanto à conservação, restauro, decoração e datação Maria de Fátima Abraços / Licínia Wrench

1277 “Casa Romana” do Castro de São Domingos (Cristelos, Lousada): Escavação, Estudo e Musealização Paulo André de P. Lemos

1291 A arqueobotânica no Castro de Guifões (Matosinhos, Noroeste de Portugal): O primeiro estudo carpológico

Luís Seabra / Andreia Arezes / Catarina Magalhães / José Varela / João Pedro Tereso 
1305 Um Horreum Augustano na Foz do Douro (Monte do Castelo de Gaia, Vila Nova de Gaia) Rui Ramos

1311 Ponderais romanos na Lusitânia: padrões, formas, materiais e contextos de utilização Diego Barrios Rodríguez

1323 Um almofariz centro-itálico na foz do Mondego

Marco Penajoia

1335 Estruturas romanas de Carnide - Lisboa Luísa Batalha / Mário Monteiro / Guilherme Cardoso

1347 O contexto funerário do sector da "necrópole NO" da Rua das Portas de S. Antão (Lisboa): o espaço, os artefactos, os indivíduos e a sua interconectividade na interpretação do passado Sílvia Loja, José Carlos Quaresma, Nelson Cabaço, Marina Lourenço, Sílvia Casimiro, Rodrigo Banha da Silva, Francisca Alves-Cardoso

${ }_{1361}$ Povoamento em época Romana na Amadora - resultados de um projeto pluridisciplinar Gisela Encarnação / Vanessa Dias

1371 A Arquitectura Residencial em Mirobriga (Santiago do Cacém): contributo a partir de um estudo de caso Filipe Sousa / Catarina Felício

${ }_{1385}$ O fim do ciclo. Saneamento e gestão de resíduos nos edifícios termais de Mirobriga (Santiago do Cacém)

Catarina Felício / Filipe Sousa

1399 Balsa, Topografia e Urbanismo de uma Cidade Portuária Vítor Silva Dias / João Pedro Bernardes / Celso Candeias / Cristina Tété Garcia

1413 No Largo das Mouras Velhas em Faro (2017): novas evidências da necrópole norte de Ossonoba e da sua ocupação medieval Ricardo Costeira da Silva / Paulo Botelho / Fernando Santos / Liliana Nunes

1429 Instrumentos de pesca recuperados numa fábrica de salga em Ossonoba (Faro) Inês Rasteiro / Ricardo Costeira da Silva / Paulo Botelho

1439 A Necrópole Romana do Eirô, Duas Igrejas (Penafiel): intervenção arqueológica de 2016 Laura Sousa / Teresa Soeiro

1457 Ritual, descarte ou afetividade? A presença de Canis lupus familiaris na Necrópole Noroeste de Olisipo (Lisboa)

Beatriz Calapez Santos / Sofia Simões Pereira / Rodrigo Banha da Silva / Sílvia Casimiro / Cleia Detry / Francisca Alves Cardoso

1467 Dinâmicas económicas em Bracara na Antiguidade Tardia Diego Machado / Manuela Martins / Fernanda Magalhães / Natália Botica

1479 Cerâmicas e Vidros da Antiguidade Tardia do Edifício sob a Igreja do Bom Jesus (Vila Nova de Gaia) Joaquim Filipe Ramos

1493 Novos contributos para a topografia histórica de Mértola no período romano e na Antiguidade Tardia Virgílio Lopes

\section{8. Época Medieval}

1511 Cerâmicas islâmicas no Garb setentrional "português": algumas evidências e incógnitas Constança dos Santos / Helena Catarino / Susana Gómez / Maria José Gonçalves / Isabel Inácio / Gonçalo Lopes / Jacinta Bugalhão / Sandra Cavaco / Jaquelina Covaneiro / Isabel Cristina Fernandes / Ana Sofia Gomes 
1525 Contributo para o conhecimento da cosmética islâmica, em Silves, durante a Idade Média Rosa Varela Gomes

1537 Yábura e o seu território - uma análise histórico-arqueológica de Évora entre os séculos VIII-XII José Rui Santos

1547 A encosta sul do Castelo de Palmela - resultados preliminares da escavação arqueológica Luís Filipe Pereira / Michelle Teixeira Santos

1559 A igreja de São Lourenço (Mouraria, Lisboa): um conjunto de silos e de cerâmica medieval islâmica

Andreia Filipa Moreira Rodrigues

1571 O registo material de movimentações populacionais no Médio Tejo, durante os séculos XII-XIII. Dois casos de "sunken featured buildings", nos concelhos de Cartaxo e Torres Novas Marco Liberato / Helena Santos / Nuno Santos

1585 O nordeste transmontano nos alvores da Idade média. Notas para reflexão Ana Maria da Costa Oliveira

1601 Sepulturas escavadas na rocha do Norte de Portugal e do Vale do Douro: primeiros resultados do Projecto SER-NPVD

Mário Jorge Barroca / César Guedes / Andreia Arezes / Ana Maria Oliveira

1619 "Portucalem Castrum Novum" entre o Mediterrâneo e o Atlântico: o estudo dos materiais cerâmicos alto-medievais do arqueossítio da rua de D. Hugo, nํ. 5 (Porto) João Luís Veloso

1627 A Alta Idade Média na fronteira de Lafões: notas preliminares sobre a Arqueologia no Concelho de Vouzela

Manuel Luís Real / Catarina Tente

1641 Um conjunto cerâmico medieval fora de portas: um breve testemunho aveirense Susana Temudo

${ }_{1651}$ Os Lóios do Porto: uma perspetiva integrada no panorama funerário da Baixa Idade Média à Época Moderna em meios urbanos em Portugal

Ana Lema Seabra

1659 O Caminho Português Interior de Santiago como eixo viário na Idade Média Pedro Azevedo

1665 Morfologia Urbana: Um exercício em torno do Castelo de Ourém André Donas-Botto / Jaqueline Pereira

1677 Intervenção arqueológica na Rua Marquês de Pombal/Largo do Espírito Santo (Bucelas, Loures)

Florbela Estêvão / Nathalie Antunes-Ferreira / Dário Ramos Neves / Inês Lisboa

1691 O Cemitério Medieval do Poço do Borratém e a espacialidade funerária na cidade de Lisboa Inês Belém / Vanessa Filipe / Vasco Noronha Vieira / Sónia Ferro / Rodrigo Banha da Silva

1705 Um Espaço Funerário Conventual do séc. XV em Lisboa: o caso do Convento de São Domingos da Cidade Sérgio Pedroso / Sílvia Casimiro / Rodrigo Banha da Silva / Francisca Alves Cardoso

\section{9. Época Moderna e Contemporânea}

1721 Arqueologia Moderna em Portugal: algumas reflexões críticas em torno da quantificação de conjuntos cerâmicos e suas inferências históricas e antropológicas Rodrigo Banha da Silva / André Bargão / Sara da Cruz Ferreira

1733 Faianças de dois contextos entre os finais do século XVI e XVIII do Palácio dos Condes de Penafiel, Lisboa

Martim Lopes / Tomás Mesquita 
1747 Um perfil de consumo do século XVIII na foz do Tejo: O caso do Mercado da Ribeira, Lisboa Sara da Cruz Ferreira / Rodrigo Banha da Silva / André Bargão

1761 Os Cachimbos dos Séculos XVII e XVIII do Palácio Mesquitela e Convento dos Inglesinhos (Lisboa)

Inês Simão / Marina Pinto / João Pimenta / Sara da Cruz Ferreira / André Bargão / Rodrigo Banha da Silva

1775 "Tomar os fumos da erua que chamão em Portugal erua sancta». Estudo de Cachimbos provenientes da Rua do Terreiro do Trigo, Lisboa

Miguel Martins de Sousa / José Pedro Henriques / Vanessa Galiza Filipe

1787 Cachimbos de Barro Caulínitico da Sé da Cidade Velha (República de Cabo Verde)

Rodrigo Banha da Silva / João Pimenta / Clementino Amaro

1801 Algumas considerações sobre espólio não cerâmico recuperado no Largo de Jesus (Lisboa) Carlos Boavida

1815 Adereços de vidro, dos séculos XVI-XVIII, procedentes do antigo Convento de Santana de Lisboa (anéis, braceletes e contas)

Joana Gonçalves / Rosa Varela Gomes / Mário Varela Gomes

1837 Da ostentação, luxo e poder à simplicidade do uso quotidiano: arqueologia e simbologia de joias e adornos da Idade Moderna Portuguesa Jéssica Iglésias

1849 Os amuletos em Portugal - dos objetos às superstições: o coral vermelho Alexandra Vieira

1865 Cerâmicas de Vila Franca de Xira nos séculos XV e XVI Eva Pires

1879 «Não passa por teu o que me pertence». Marcas de individualização associadas a faianças do Convento de Nossa Senhora de Aracoeli, Alcácer do Sal Catarina Parreira / Íris Fragoso / Miguel Martins de Sousa

1891 Cerâmica de Leiria: alguns focos de produção

Jaqueline Pereira / André Donas-Botto

1901 Os Fornos na Rua da Biquinha, em Óbidos Hugo Silva / Filipe Oliveira

1909 A casa de Pêro Fernandes, contador dos contos de D. Manuel I: o sítio arqueológico da Silha do Alferes, Seixal (século XVI) Mariana Nunes Ferreira

1921 O Alto da Vigia (Sintra) e a vigilância e defesa da costa Alexandre Gonçalves / Sandra Santos

1937 O contexto da torre sineira da Igreja de Santa Maria de Loures Paulo Calaveira / Martim Lopes

1949 A Necrópole do Hospital Militar do Castelo de São Jorge e as práticas funerárias na Lisboa de Época Moderna Susana Henriques / Liliana Matias de Carvalho / Ana Amarante / Sofia N. Wasterlain

1963 SAND - Sarilhos Grandes Entre dois Mundos: o adro da Igreja e a Paleobiologia dos ossos humanos recuperados

Paula Alves Pereira / Roger Lee Jesus / Bruno M. Magalhães

1975 Expansão urbana da vila de Cascais no século XVII e XVIII: a intervenção arqueológica na Rua da Vitória no 15 a 17

Tiago Pereira / Vanessa Filipe

1987 Novos dados para o conhecimento do Urbanismo de Faro em época Moderna Ana Rosa 
1995 Um exemplo de Arqueologia Urbana em Alcoutim: o Antigo Edifício dos CTT Marco Fernandes / Marta Dias / Alexandra Gradim / Virgílio Lopes / Susana Gómez Martínez

2007 Palácio dos Ferrazes (Rua das Flores/Rua da Vitória, Porto): a cocheira de Domingos Oliveira Maia

Francisco Raimundo

2021 As muitas vidas de um edifício urbano: História, Arqueologia e Antropologia no antigo Recreatório Paroquial de Penafiel Helena Bernardo / Jorge Sampaio / Marta Borges

2035 O convento de Nossa Senhora da Esperança de Ponta Delgada: o contributo da arqueologia para o conhecimento de um monumento identitário João Gonçalves Araújo / N’Zinga Oliveira

2047 Arqueologia na ilha do Corvo... em busca da capela de Nossa Senhora do Rosário Tânia Manuel Casimiro / José Luís Neto / Luís Borges / Pedro Parreira

2059 Perdidos à vista da Costa. Trabalhos arqueológicos subaquáticos na Barra do Tejo Jorge Freire / José Bettencourt / Augusto Salgado

2071 Arqueologia marítima em Cabo Verde: enquadramento e primeiros resultados do projecto CONCHA

José Bettencourt / Adilson Dias / Carlos Lima / Christelle Chouzenoux / Cristóvão Fonseca / Dúnia Pereira / Gonçalo Lopes / Inês Coelho / Jaylson Monteiro / José Lima / Maria Eugénia Alves / Patrícia Carvalho / Tiago Silva

2085 Trabalhos arqueológicos na Cidade Velha (Ribeira Grande de Santiago, Cabo Verde): reflexões sobre um projecto de investigação e divulgação patrimonial André Teixeira / Jaylson Monteiro / Mariana Mateus / Nireide Tavares / Cristovão Fonseca / Gonçalo C. Lopes / Joana Bento Torres / Dúnia Pereira / André Bargão / Aurélie Mayer / Bruno Zélie / Carlos Lima / Christelle Chouzenoux / Inês Henriques / Inês Pinto Coelho / José Lima / Patrícia Carvalho / Tiago Silva

2103 A antiga fortificação de Quelba / Khor Kalba (E.A.U.). Resultados de quatro campanhas de escavações, problemáticas e perspectivas futuras Rui Carita / Rosa Varela Gomes / Mário Varela Gomes / Kamyar Kamyad

2123 Colónias para homens novos: arqueologia da colonização agrária fascista no noroeste ibérico Xurxo Ayán Vila / José Mạ . Señorán Martín 


\title{
ARQUEOLOGIA URBANA: A CIDADE DE LAGOS COMO CASO DE ESTUDO
}

\author{
Cátia Neto ${ }^{1}$
}

\begin{abstract}
RESUMO
Devido ao acelerado ritmo de desenvolvimento urbano actual de muitas das cidades, a Arqueologia urbana tende a projetar-se, contribuindo para um novo enquadramento regulamentar que exige este tipo de trabalhos nos centros históricos, sendo necessário adaptar e desenvolver métodos para trabalhar em ambientes urbanos. Uma das principais problemáticas, se não a principal, associada à Arqueologia urbana é justamente a questão de a Arqueologia de salvamento/preventiva desempenhada por empresas de Arqueologia ser vista por muitos dos especialistas como um impedimento à produção de conhecimento acerca da cidade e da sua história, pelo que se tentará perceber porque é que a Arqueologia Preventiva é vista como um impedimento à produçao de conhecimento.
\end{abstract}

Palavras-Chave: Arqueologia Urbana, Arqueologia Preventiva, Lagos (Portugal).

\begin{abstract}
Due to the rapid pace of urban development in many cities, urban archaeology tends to project itself, contributing to a new regulatory framework that requires this type of work in the historic centers, being necessary to adapt and develop methods to work in urban environments. One of the main problems, if not the main one, associated with urban archaeology is precisely the question of the rescue/preventive archaeology performed by archaeology companies being seen by many of the specialists as an impediment to the production of knowledge about the city and its history, so one will try to understand why Preventive Archaeology is seen as an impediment to the production of knowledge.
\end{abstract}

Keywords: Urban Archaeology, Preventive Archaeology, Lagos (Portugal).

\section{INTRODUÇÃO}

A Arqueologia estava inicialmente muito relacionada com a pré-história, com o avançar do tempo passou a aplicar-se a períodos cada vez mais recentes, como a Idade Média, a história contemporânea, a época moderna e mesmo o período industrial. Perdendo o seu carácter maioritariamente académico e sazonal, de quando era levada acabo apenas no verão em locais remotos e rurais, passando para os centros urbanos onde há intervenções a decorrer diariamente. Devido ao acelerado ritmo de desenvolvimento urbano actual de muitas das cidades, a Arqueologia urbana tende a projetar-se, contribuindo para um novo enquadramento regulamentar que exige este tipo de trabalhos nos centros históricos (Madeira, s.d.) e não só. Mas não sem os seus desafios, pois foi necessário adaptar e desenvolver mé- todos para trabalhar em ambientes urbanos (Madeira, s.d.).

Os meios urbanos centralizam instituições políticas e administrativas, importantes espaços de culto (ou com carga simbólica), economias complexas com espacialização do trabalho e estratificação social. (Madeira, s.d.). Francisco Sande Lemos entende a cidade "como espaço vivido em comunidade é um lugar único, onde se poderá discutir, sem axiomas ou imposições, os caminhos que se pretendem seguir." (Lemos, 2002: 252). As cidades são um arqueossítio por excelência (Lemos, 2002), uma vez que os locais de preferência para o estabelecimento de comunidades têm sido essencialmente os mesmos ao longo dos tempos, o que se verifica é que com a evolução estes se vão expandindo mas mantêm, regra geral, o seu núcleo primitivo. Para além de que simples fragmentos cerâmicos abandonados em níveis de ater-

1. Mestranda em Arqueologia pela Faculdade de Letras da Universidade de Lisboa; catia.neto@campus.ul.pt. 
ro, por exemplo, poderão contribuir para identificar relações comerciais ou alterações socioeconómicas, tanto ou mais que certos registos escritos (Madeira, s.d.). A Arqueologia urbana pode recuperar informações sobre estes e outros aspetos das comunidades do passado através de métodos de trabalho de campo e laboratório cada vez mais em crescente especialização e desenvolvimento (Madeira, s.d.). Este é um domínio da Arqueologia que se tem desenvolvido e regido por leis, protocolos e políticas concretas, procurando fornecer informações independentes e complementares à documentação escrita (Madeira, s.d.), e que em última análise procura não deixar que as memórias e identidades se percam.

Apesar das dificuldades que têm encontrado, os arqueólogos têm contribuído para uma melhor compreensão das origens da urbanização e de aspetos relacionados com o saneamento, transporte, habitação e relações sociais e económicas (Madeira, s.d.). Uma das principais problemáticas, se não a principal, associada à Arqueologia urbana é justamente a questão de a Arqueologia de salvamento/preventiva desempenhada por empresas de Arqueologia ser vista por muitos dos especialistas como um impedimento à produção de conhecimento acerca da cidade e da sua história.

Assim o objectivo inicial deste trabalho foi olhar para um centro urbano do território português em que se verifica um crescente número de intervenções arqueológicas e um papel ativo dos órgãos municipais no que toca a Arqueologia, com o objectivo de compreender de que forma a integração de equipas de Arqueologia nas autarquias, a dominante presença da Arqueologia preventiva e as empresas de Arqueologia têm contribuído para o conhecimento acerca da cidade. Pelas atípicas circunstâncias dos últimos tempos, não foi possível a recolha de parte da informação necessária, pelo que se tentará perceber porque é que a Arqueologia Preventiva é vista como um impedimento à produçao de conhecimento.

\section{LAGOS, CIDADE HISTÓRICA}

Porquê a cidade de Lagos como caso de estudo? Desde há muito que a Administração Central portuguesa olha para a cidade de Lagos como cidade histórica, cuja preservação seria a preservação da memória identitária dos portugueses (Morán e Parreira, 2009), sobretudo devido aos indícios da sua longa ocupação (Morán, 2006). Pela sua posição geográfica e mor- fologia costeira apresenta as condições ideias para o acolhimento de tráfego marítimo, nomeadamente proveniente do Mediterrâneo, com destino ao Atlântico, o que conduziu à predominância de Lagos como principal cidade marítima na zona do Barlavento Algarvio (Fraga, 2013).

Foi Estácio da Veiga quem conduziu ao reconhecimento da importância arqueológica do Centro Histórico de Lagos, através da valorização o achado de numerosas moedas romanas ao desentulhar os edifícios da cidade arrasados pelo terramoto de 1755 e da referência à presença de alicerces de construção romana na Rua de Nossa Senhora da Graça (explorados parcialmente em 1878 ), bem como ao acentuar do potencial arqueológico de outros locais da área de expansão da cidade (Veiga, 1910: 220-221; Veiga, 2006: 127).

Leite de Vasconcelos, em 1894, sublinha o interesse arqueológico dos antigos cemitérios urbanos, nomeadamente o da paróquia de Santa Maria da Graça, e mais tarde, em 1900, explora parte da necrópole do Monte Molião (Diaz-Guardamino et al., 2006; Pereira, 1997: 49).

Algumas décadas mais tarde, José Formosinho, fundador do Museu Regional de Lagos em 1930, regista numerosas ocorrências de interesse arqueológico no Centro Histórico da cidade e na sua envolvente próxima, fazendo recolhas e pesquisas que incorpora no museu, dando a conhecer vários locais de achados conduziu ao reconhecimento da importância arqueológica do Centro Histórico de Lagos (Morán e Parreira, 2009: 902).

A ocupação humana do que hoje consideramos Lagos inicia-se no $5^{\circ}$ milénio (Morán,2006), teve depois uma ocupação pré-romana, já com características marítimas (Blot,2003:275) e durante o período clássico terá sido um dos principais portos da antiguidade - inicialmente estaria localizado no sítio de Monte Molião e mais tarde transferiu-se para a atual localização da cidade. Durante a época Medieval/Islâmica, é uma das localidades fortificadas que protegem a capital muçulmana estabelecida em Silves (Coutinho, 2001: 13), mais tarde ao ser incorporada no território nacional torna-se parte da linha costeira de defesa (Fragas, 2013) e continua a desenvolver relações comerciais com os territórios muçulmanos, tornando-se num importante porto de escala nas rotas internacionais que na época ligavam o Mediterrâneo aos principais centros mercantis do Norte de África (Loureiro, 1991 :16-17 apud 
Fragas, 2013). Estas rotas e as tensões entre cristãos e muçulmanos, são o palco perfeito para o corso português (Barbosa, 1993: 25) e mais tarde o Infante D. Henrique escolhe a cidade de Lagos como base marítima para as expedições dos Descobrimentos (Coelho, 1992: 13 apud Fragas, 2013). O acesso a água potável, as boas zonas de varação e as amplas áreas de ancoragem, são as razões que fazem de Lagos o ponto de paragem de preferência mantendo-se um dos principais portos de abastecimento do Algarve (Fragas,2013) mesmo depois da transferência para Lisboa de companhias como a Casa da Guiné (Paula, 1992: 38). O declínio de Lagos inicia-se com o terramoto de 1775, que arrasou por completo a cidade e foi responsável pelo assoreamento da barra de acesso ao porto (Fragas, 2013).

Porém a ideia de Lagos como "cidade dos Descobrimentos" e a forte associação à figura do Infante de Sagres levaram à desconsideração de outros tantos testemunhos materiais de uma longa trajetória histórica e de grande relevância nacional (Morán e Parreira, 2009).

A actividade arqueológica sistemática assegurada ao longo da primeira década do presente milénio contribuiu para que amplos sectores da população juntamente com responsáveis e técnicos que gerem o território municipal compreendessem que a cidade atual se sobrepõe a ocupações pré-históricas, proto-históricas, romanas, medievais e modernas, pelo que a "cidade dos Descobrimentos" constitui apenas um momento de um amplo e complexo processo histórico (Morán e Parreira, 2009: 905).

Mas não pode ser esquecido que Lagos é também uma estância balnear, por excelência, sobretudo desde a década de cinquenta, o que fez com que fosse submetida às pressões urbanísticas que pouco a pouco alteram a fisionomia da paisagem cultural e que por vezes colidem com o património arqueológico pré-existente (Morán e Parreira, 2009). Durante a década de oitenta o interesse imobiliário incidiu essencialmente na área imediatamente circundante ao Centro Histórico da cidade, definido pela fortificação quinhentista, mas a partir da década de noventa devido à falta de incentivos à política de reabilitação e ao favorecimento da política de renovação urbana ouve frequentes demolições que deram lugar a novas construções que foram destruindo a imagem tradicional da cidade (Morán e Parreira, 2009). Simultaneamente, decorre a expansão dos bairros periféricos com uma política de so- brevalorização do solo edificável, o que contribuiu para a construção em altura, tal como o afastamento entre a cidade e o mar, consequência da renovação das ligações rodoviárias dos anos cinquenta e sessenta, dois factores que contribuíram para a descaracterização da silhueta tradicional da cidade (Morán e Parreira, 2009).

\section{ARQUEOLOGIA URBANA: CONCEITO E EVOLUÇÃO}

O crescimento exponencial dos centros urbanos tornou indispensável refletir acerca do seu passado, evolução e presente, procurando compreender de forma aprofundada os elementos dinâmicos que podem assegurar a sua continuidade futura em termos harmoniosos (Martins e Ribeiro, 2009/2010: 149). O papel da Arqueologia é, no geral, reconhecido como fundamental para este processo, pelo seu contributo para a articulação do passado e presente das cidades, para revelar a sua origem, comprovar ou desmentir teorias da sua fundação ou interpretações acerca da sua evolução (Martins e Ribeiro, 2009/2010; Lemos e Martins,1992).

O conceito de Arqueologia urbana, de acordo com a sua origem e evolução nos textos especializados, em particular na Europa do pós-guerra, deve ser aplicado exclusivamente ao estudo arqueológico das cidades atuais (Lemos e Martins, 1992).

Foi a partir das décadas de sessenta e setenta do século $\mathrm{XX}$, com o crescimento demográfico das cidades e a renovação dos centros históricos, que o Estado, os municípios e a própria Arqueologia se viram confrontados com a questão do estudo e salvaguarda das evidências materiais da história urbana (Lemos e Martins, 1992). Datam dos anos sessenta do século $\mathrm{XX}$ as primeiras experiências que farão nascer a Arqueologia urbana, com a aprovação da Carta de Veneza em 1964 (um dos primeiros documentos a referir a importância da cidade como monumento histórico) a cidade passa a ser um sítio único, pluri-estratigrafado, cuja escavação permite resolver problemas histórico (Martins e Ribeiro, 2009/2010). Isto pressupunha que para cada cidade existisse um projecto de investigação consistente, com objetivos concretos, que permitissem avaliar e valorizar as suas particularidades evolutivas (Martins e Ribeiro, 2009/2010:150).

A sistematização de intervenções em cidades históricas foi uma consequência direta da actividade cons- 
trutiva que se deu no pós-guerra (Martins e Ribeiro, 2009/2010: 153). Esta realidade está particularmente bem documentada no Reino Unido, onde a renovação urbanística, resultante do crescimento económico das décadas de cinquenta e sessenta, sem qualquer atenção ao património, acabou por gerar o descontentamento e a alteração das políticas do uso do solo (McGill, 1995:). Cenário que permite considerar o Reino Unido como berço da moderna Arqueologia urbana (Martins e Ribeiro, 2009/2010). A Arqueologia urbana inglesa rapidamente afirmou conceitos, objetivos e metodologias para este ramo, afectando a sua prática noutros países, definindo que o desenvolvimento das cidades atuais deveria ser acompanhado por uma correta investigação do seu passado e da prática do acompanhamento arqueológico dos novos empreendimentos (Martins e Ribeiro, 2009/2010; Biddle e Hudson, 1973).

A Arqueologia urbana passou assim a ser entendida como Arqueologia na cidade e da cidade, sendo o seu objectivo conhecer a cidade como facto histórico, em termos temporais, espaciais e materiais (Martins e Ribeiro, 2009/2010:150).

A aceleração do ritmo construtivo, a modernização dos centros históricos e o aumento da capacidade de intervenção na estrutura urbanística, sob pressão da especulação imobiliária, são factores que condicionaram a evolução da Arqueologia urbana na Europa (Martins e Ribeiro, 2009/2010:150).

Durante os anos 70 assistiu-se a uma renovação das metodologias e na conceptualização das bases teóricas, tendo sido definido um objectivo claro para a Arqueologia urbana: "investigação da cidade, como fenómeno urbano, na sua integridade, variabilidade e longa duração, procurando-se, deste modo, equiparar as escavações urbanas a quaisquer outras realizadas com fins científicos." (Martins e Ribeiro, 2009/ 2010: 153).

Os fundamentos teóricos e metodológicos da Arqueologia urbana essencialmente os mesmo que da Arqueologia no geral, mas apresenta algumas especificidades, resultantes de as cidades enquanto objecto de estudo, serem espaços de constante e contínua renovação (Madeira, s.d.). Pelo que sob uma perspectiva estritamente técnica a Arqueologia urbana implica métodos próprios, tendo em conta a complexidade estratigráfica dos subsolos das cidades históricas em que os sucessivos níveis de ocupação se sobrepõem, recortam, etc... (Lemos e Martins, 1992). O que exige um rigoroso registo, bem como um profundo conhecimento dos materiais de diferentes épocas (Lemos e Martins, 1992). E deverá promover a conservação dos vestígios in situ, o que implica desenvolver e aplicar métodos de análise e de registo não destrutivos e instrumentos, tais como a avaliação da potencialidade arqueológica dos solos e cartas de risco, que devem ser tidos em consideração aquando da planificação urbana (Martins e Ribeiro, 2009/2010: 168).

A sua prática passou por esta razão a exigir equipas interdisciplinares e profissionais, responsáveis por realizar as escavações, gerir a informação, elaborar e processar os dados e pela produção de conhecimento (Martins e Ribeiro, 2009/2010: 153). A investigação de uma cidade era encarada como um projecto a longo prazo, pelo que a defesa/manutenção destas equipas, ou urban units como Biddle (1974) as designa, passa também a ser um aspeto importante (Biddle, 1974: 95-112). Foi-se, assim, criando um novo mercado de trabalho que permitiu a profissionalização de jovens arqueólogos (Martins e Ribeiro, 2009/2010).

No nosso país realizaram-se sérios esforços para que se desenvolvesse uma política estruturada, mas estes são pouco conhecidos, ficando o seu registo perdido em arquivos de jornais, diários e seminários e nos volumosos processos do IPPC (Lemos e Martins, 1992). A influência do paradigma da Arqueologia urbana inglesa faz-se sentir em Portugal com o lançamento do "Projecto de Salvamento de Bracara Augusta”, em 1976, e a criação da equipa permanente do Campo Arqueológico de Braga, cuja direção científica e técnica estava afeta à Universidade do Minho (Martins e Ribeiro, 2009/2010:154). Este foi um projecto pioneiro, pois até então praticamente não existia Arqueologia urbana em Portugal (Delgado et ali, 1989). Seguiram-se mais algumas iniciativas, nomeadamente: em Setúbal, graças ao Museu de Arqueologia e Etnografia de Setúbal; em Évora, com o apoio do Serviço de Arqueologia do IPPC; em Mértola e Silves, graças ao interesse dos respetivos municípios; em Faro graças à Unidade de Arqueologia da Universidade do Algarve (Lemos e Martins, 1992).

$\mathrm{Na}$ fase inicial da Arqueologia urbana, durante a segunda metade da década de setenta e nos primeiros anos da década de oitenta, houve de facto um ensaio de resposta, que progressivamente se foi diluindo, face às grandes dificuldades que os salvamentos urbanos oferecem (Lemos e Martins, 1992). O pro- 
gressivo desinvestimento por parte do Estado na Arqueologia urbana, que se sentiu em vários países, a partir dos anos 8o, veio impossibilitar quer a formação quer a sobrevivência de equipas destinadas ao estudo das cidades, criando-se um panorama em que a Arqueologia de contrato surge como resposta ao número crescentes de intervenções de caráter preventivo desencadeadas pelo crescimento e renovação urbana e pela aplicação de condicionantes aos solos das cidades (Martins e Ribeiro, 2009/2010: 151). As intervenções arqueológicas nas cidades nunca chegaram a adquirir um estatuto de Arqueologia urbana, nem mesmo o caso de Bracara Augusta, pois esse estatuto exigia meios financeiros e infraestruturas humanas ao dispor das entidades responsáveis pelo salvamento, sejam elas Universidades, Camaras Municipais ou os próprios serviços do IPPC (Lemos e Martins, 1992).

A Arqueologia urbana começou a distanciar-se da Arqueologia académica - pois esta segunda é cronologicamente orientada e marcadamente sazonal -, foram definidos novos parâmetros de atuação, nomeadamente quanto à avaliação da potencialidade informativa dos solos urbanos, através de cartas de risco, com o objectivo de minimizar os impactos negativos (Biddle e Hudson, 1973). A catalogação dos recursos do subsolo urbano, a sua integração nas normativas de planificação e o estabelecer de condicionantes sobre a edificabilidade das áreas urbana, de acordo com o seu potencial arqueológico, tornaram-se prática corrente em algumas cidades europeias, se bem que os modelos de gestão e os objetivos variam substancialmente de cidade para cidade (Martins e Ribeiro, 2009/2010: 155).

Porém o crescimento das cidades ocorreu quase sempre à margem de planos de urbanização aprovados, o que impedia ações programadas, mesmo nas cidades em que existem equipas de intervenção (Lemos e Martins, 1992). De modo que a pressão construtiva e o consequente aumento do número de escavações acabaram por conduzir ao crescimento das intervenções de salvamento, acompanhado por um progressivo desaparecimento das unidades permanentes de intervenção urbana, por serem economicamente insustentáveis (Martins e Ribeiro, 2009/2010:155).

São raros os casos em que a Arqueologia urbana conheceu um forte investimento por parte dos organismos de tutela, salvo no Reino Unido, França, Itália e países nórdicos, que empreenderam programas de investigação arqueológica tendo em vista estudar a evolução das suas cidades (Martins e Ribeiro, 2009/2010).

Isto levou a que nos anos oitenta se generalizasse um novo entendimento do conceito, que passava pele Arqueologia em meio urbano, que designa as escavações ad hoc, resultado da necessidade de realizar intervenções prévias à execução de obras (Martins e Ribeiro, 2009/2010). Estas eram destituídas de qualquer problemática ou objetivos científicos relacionados com o estudo das cidades (Martins e Ribeiro, 2009/2010), para além de que forneciam substancial quantidade de dados, os quais não eram processados e estudados em tempo útil, de modo a se transformarem em conhecimento científico e a permitirem o seu retorno social (Carver, 1996 apud Martins e Ribeiro, 2009/2010). O que constitui um dos maiores desafios, pois por vezes é necessário esperar anos até que seja possível articular os dados obtidos, pois tornou-se habitual que os trabalhos arqueologicos a decorrer em ruas vizinhas sejam desenvolvidos sem qualquer ligação ou consonância (Lemos e Martins, 1992; Madeira, 2011). É certo que a publicação nunca foi uma preocupação da Arqueologia preventiva, mas a implementação do princípio do "poluidor/pagador" (divulgado em Inglaterra e que rapidamente se difundiu por outros países) veio agravar esta situação, uma vez que raramente estão contemplados nos cadernos de encargos o estudo e publicação de resultados (Rodríguez Tamiño, 2004; Martins e Ribeiro, 2009/2010).

$\mathrm{O}$ alheamento da Arqueologia urbana face à divulgação do conhecimento acentuou-se também com o desenvolvimento da Arqueologia contratual, realidade especialmente bem documentada na Península Ibérica (Rodríguez Tamiño, 2004), entre os anos de 1976 e 2000 realizaram-se apenas três colóquios de Arqueologia Urbana e destes apenas os dois primeiros tiveram as suas atas publicadas, tornando clara a ausência de uma plataforma nacional, com periodicidade, onde sejam discutidos aspetos como politicas, leis, métodos e conflitos ou se divulguem descobertas, noticias preliminares ou sínteses (Lemos, 2002). O crescimento da Arqueologia de salvamento fez-se acompanhar do crescimento da Arqueologia contratual, pois só esta era capaz de dar resposta à crescente procura no mercado de entidades competentes para a realização de escavações prévias ao início das obras (Martins e Ribeiro, 2009/2010: 157). 
Isto fez com que as escavações urbanas se traduzissem numa acumulação de dados por tratar, estudare publicar que não reverteu num efetivo conhecimento sobre o passado das cidades e com que a prática da Arqueologia urbana se tenha reduzido a simples acompanhamentos e escavações preventivas que não enquadram um projecto de investigação (Martins e Ribeiro, 2009/2010: 159). (Martins e Ribeiro, 2009/2010: 158).

De modo que a Arqueologia urbana deve ser entendida como a investigação do património arqueológico da cidade, que atua para o conhecimento da história urbana mas também quando novas construções e infraestruturas implicam a substituição de antigos edificados ou a remoção de depósitos pluri-estratigrafados que conformam o subsolo, quando é impossível evitar a sua afetação (Martins e Ribeiro, 2009/2010: 168).

\section{QUESTÕES PROCESSUAIS: LEGISLAÇÃO}

Em Portugal durante as décadas de setenta e oitenta decorreu um expressivo debate sobre os objetivos, métodos, modelos e regulamentação jurídica da Arqueologia urbana (Lemos, 2006: 15). Uma das consequências da urbanização é a perda rápida de dados arqueologicos. A promulgação de legislação de protecção dos recursos arqueológicos urbanos é uma forma de retardar essa perda, todavia a aplicação prática destas diretivas legais não se tem provado eficaz em todos os casos (Madeira, s.d.).

Em 1985 existia um artigo específico na Lei de Bases do Património que contemplava a Património Arqueológico Urbano (Lemos, 2006). Em 1992 foi assinada a Convenção Europeia para a Protecção do Património Arqueológico, embora a Carta de Malta não se refira expressamente ao património arqueológico urbano, efetuaram-se reuniões sobre esse domínio no Concelho da Europa, das quais resultou um abrangente relatório, Report on the situation of Urban Archaeology in Europe, no qual não existe qualquer relatório sobre Portugal (Lemos, 2006). Existe ainda o European Code of Good Practice: Archaeology and the Urban Project, divulgado em 2000, que apesar da sua importância está pouco divulgado no nosso país (Lemos, 2006).

A carta de Malta foi ratificada em 1997, em 1998 é plenamente adoptada pelo Estado Português (Lemos, 2008/o9) e os seus princípios foram introduzidos em vários textos legais, nomeadamente na
Lei de Bases do Património de 2001 (Lemos, 2006). Importa ainda realçar que a aplicação da Carta de Malta em Portugal teve os seus aspetos positivos e negativos; quanto aos primeiros tem-se a criação de mais postos de trabalho na Arqueologia, a multiplicação de medidas preventivas e minimizadoras, de entre as quais os trabalhos prévios e os acompanhamentos de obras, no que toca aos segundos, tem-se o facto de uma série de processos distintos acabarem por ser colocados "no mesmo saco", a Arqueologia de salvamento (Lemos, 2006).

No caso concreto da cidade de Lagos foi sobretudo a partir de 2005 que a Arqueologia passou a desempenhar um papel mais interventivo no licenciamento de obras no Centro Histórico e aro urbano envolvente, existindo ainda uma Licença Única para a execução de demolições e construções que incluam trabalhos arqueológicos, onde são listadas todas as condicionantes (Morán e Parreira, 2009: 913). Nos casos em que se verifique o incumprimento das condicionantes a autarquia dispõe de capacidade de atuação autónoma, podendo impor medidas corretivas, nomeadamente, em casos em que o património arqueológico não classificado é afetado (não por ser património arqueológico mas pelo incumprimento das condicionantes impostas) (Morán e Parreira, 2009: 913). Mas estas normas não foram pensadas exclusivamente para os erros cometidos pelos promotores. Nos casos em que há um erro processual por parte da autarquia, seja quando há licenciamento de obras em áreas onde se presuma existir vestígios, em que cabe à autarquia executar diretamente os trabalhos preventivos, seja quando o erro processual é detetado após a execução de trabalhos que afetaram património arqueológico, compete à autarquia a avaliação dos danos e a implementação dos trabalhos que pareçam necessários, acarretando com os seus custos (Morán e Parreira, 2009).

Posteriormente em 2008 foi criado o Serviço de Arqueologia Urbana, dentro da Divisão de Gestão Urbana, do Departamento de Planeamento e Gestão Urbanística, cujos objetivos eram a implementação de uma política marcadamente preventiva e o desenvolvimento em simultâneo de uma investigação de qualidade, através de parcerias com Universidades e Centros de Investigação, (Morán e Parreira, 2009). Havia, portanto, um entendimento de que a justificação do investimento em Arqueologia é o processamento dos dados técnicos, e a sua conversão em conhecimento histórico que permita a sua 
devolução à comunidade (Morán e Parreira, 2009). Apesar de a divisão do estudo de uma cidade em várias parcelas cronológicas e espaciais ter um duplo efeito negativo - pois por um lado diminui a possibilidade de serem produzidas monografias e sínteses, e por outro multiplica as vozes que assumem discursos científicos sobre a cidade de tal modo que esta ignora quem são os seus interlocutores sobre matérias de património arqueológico (Lemos,2006) - estas possibilitam a redução (e se bem aplicadas a longo prazo talvez a extinção) do fosso que neste momento existe entre as escavações realizadas e o estudo e publicação dos bens culturais retirados de campo. Elena Morán e Rui Parreira afirmam, face aos resultados positivos da parceria estabelecida entre a Camara de Lagos e a Faculdade de Letras da Universidade de Lisboa para o estudo do sítio arqueológico de Monte Molião, que estas parcerias são "uma tendência que deverá ser aprofundada, com a desejável integração do meio académico no estudo da cidade e do seu território envolvente, não a penas com acções de investigação plurianual programadas mas capitalizando os dados adquiridos nas acções de prevenção, disponibilizando para estudos académicos os materiais e a documentação que os contextualiza" (Morán e Parreira, 2009: 911).

Ainda em 2008 foi feita uma revisão do Regulamento Municipal de Urbanização, Edificado, Taxas e Compensações Urbanísticas do Município de Lagos, que passa a abranger todas as obras de edificação do Município e não só do Centro Histórico (Morán e Parreira, 2009). E a partir de 2009 houve uma normalização da articulação com a Administração Central, em áreas patrimonialmente protegidas por lei. Quanto aos regulamentos em vigor no presente, existem três Planos de Urbanização (de Lagos, da Meia Praia e da Vila da Luz, este último encontra-se em revisão), as condicionantes que apresentam são bastantes semelhantes e em ambos estão identificados os sítios arqueologicos e as zonas de sensibilidade. Existem ainda onze Planos de Pormenor e apenas um, o da Zona Envolvente à Estação de Lagos não apresenta qualquer referência ao património arqueológico ou a valores culturais. Os restantes são relativamente semelhantes entre si, apresentado sempre a condicionante de que ao serem encontrados elementos arqueologicos a obra deve ser interrompida e que deve ser aplicado o disposto na Lei de Bases da Política e Regime de Proteção e Valorização do Património Cultural.
Por fim, existe ainda o atual PDM de Lagos, que data de 2015, em que encontramos o Artigo 10 ${ }^{\circ}-$ Salvaguarda do património arqueológico que estipula as condicionantes, que fazem eco da política preventiva do Serviço de Arqueologia Urbana, e que se encontram essencialmente replicadas nos Planos de Pormenor, e pode-se ler o seguinte:

1. Os processos de licenciamento ou comunicação prévia de operações urbanísticas destinadas a sítios ou zonas de sensibilidade arqueológica e paeloambiental, são instruídos com parecer relativo à componente arqueológica subscrita por arqueólogo do Município ou, na sua ausência, pela entidade de tutela.

2. Exceciona-se do disposto no número anterior os processos relativos a obras de alteração e obras de conservação desde que não afetem o subsolo em área arqueológica.

3. O aparecimento de vestígios arqueológicos durante a realização das obras abrangidas pelo n.ำ 1 obriga à paragem imediata dos trabalhos no local e à comunicação da ocorrência à Câmara Municipal e à entidade de tutela do património arqueológico ou à autoridade policial.

4. Os trabalhos só poderão ser retomados após a emissão de parecer por parte da Câmara Municipal e da entidade de tutela do património arqueológico, no prazo de 30 dias úteis, findos os quais, a omissão de pronúncia por parte de ambas as entidades determinam o levantamento automático da suspensão e a retoma dos trabalhos.

5. A suspensão da obra devido a trabalhos arqueológicos acarreta a suspensão dos prazos de vigência da licença ou comunicação prévia da obra em causa.

6. Para a salvaguarda do património arqueológico, aplica-se o regime legal em vigor.

7. A eventual atualização da Planta de Património, que acompanha o PDM, será efetuada em sede de regulamento municipal.

\section{LAGOS E A PRÁTICA ARQUEOLÓGICA}

A prática da Arqueologia de salvamento na antiga área urbana de Lagos, remonta à década de oitenta (Morán e Parreira, 2009: 903). Altura em que alguns técnicos dos Serviços de Arqueologia do IPPC, ao serem alertados pela autarquia se deslocam a Lagos com o intuito de minimizar o impacte negativo 
criado por algumas construções (Morán e Parreira, 2009: 903). Também por esta altura, Virgílio Correia escavou contextos com materiais romanos re-depositados no interior de uma conduta que, em época-moderna, encanou a Ribeira dos Touros, e foram identificadas estruturas de uma oficina de preparados de peixe romana na Rua Silva Lopes, afetadas por uma construção (Morán e Parreira, 2009: 903-904).

Situação que levou a Camara Municipal de Lagos a ponderar equipar a autarquia com pelo menos um arqueólogo (Morán e Parreira, 2009). Logo no final da década de oitenta, a arqueóloga Marta Gordilho procurava confirmar no terreno e atualizar a cartografia arqueológica do concelho de Lagos, como primeiro passo para a implementação de medidas preventivas de salvaguarda do património (Morán e Parreira, 2009: 904). Porém a partir de 1993 a autarquia ficou novamente sem arqueólogo, verificando-se um retrocesso na política de gestão do património arqueológico no Município de Lagos. De modo que a pratica da Arqueologia preventiva na área urbana de Lagos se impunha a custo, num panorama em que a criação do IPA, a reorganização do IPPAR e a alteração dos instrumentos legais de gestão do património arqueológico entre 1997 e 2001, contribuíram de forma positiva para a imposição de medidas de salvaguarda eficazes, com adopção dos dois princípios básicos pelos quais a Arqueologia preventiva e paliativa se passou a regular: a extensão ao património cultural arqueológico do princípio do "poluidor-pagador" e a aplicação metódica do princípio da conservação pelo registo científico (Morán e Parreira, 2009: 904). Os anos de 1998 e de 2001 foram marcados, em Lagos, pela destruição deliberada e sem registo por parte dos promotores, de importante património arqueológico (Morán e Parreira, 2009). Atualmente e como vai ser visto mais a frente, existem mecanismos que procuram impedir este tipo de situações.

Este panorama levou a Câmara de Lagos a reagir às insistências da tutela para que implementasse de uma maneira eficaz as medidas cautelares de salvaguarda do património arqueológico, quer nas obras de iniciativa municipal quer nas de iniciativa privada (Morán e Parreira, 2009). Por forma a dar resposta às exigências e obrigações legais decorrentes das convenções internacionais, a Arqueologia passou a ser entendida como uma especialidade incontornável na reabilitação urbana e no ordenamento do ter- ritório, como já foi visto, o que conduziu à incorporação de um sector de Arqueologia no Gabinete do Centro Histórico de Lagos e à posterior constituição do Serviço de Arqueologia Urbana, no âmbito da Divisão de Gestão Urbana da Camara Municipal de Lagos (Morán e Parreira, 2009: 904-905). O poder local passou a assumir as responsabilidades na gestão patrimonial, em consequência de a área urbana de lagos passar a ser encarada com um sítio arqueológico que contem informação relevante para o conhecimento histórico e que caracteriza identidade cultural (Morán e Parreira, 2009: 905).

Atualmente o património cultural histórico-arqueológico está naturalmente inserido na ordem cultural, social e económica contemporânea, contribuindo cada vez mais para a caracterização e identidade da cidade, mediante a preservação e valorização das suas preexistências (Morán e Parreira, 2009:905). Durante o período em que a autarquia manteve uma pequena equipa técnica operacional, ou seja, até 2005, as intervenções por parte dos arqueólogos municipais são expressivas, posteriormente continuaram a assegurar algumas intervenções no terreno mas há uma crescente externalização da prestação dos serviços (Morán e Parreira, 2009: 911-912), consequentemente uma crescente intervenção da Arqueologia empresarial, o que tem impedido que a cidade seja assumida como objecto de estudo de um projecto de investigação (Morán e Parreira, 2009). Mas a meu ver não pode ser ignorado que se não fosse a intervenção das empresas de Arqueologia, a autarquia não tinha meios humanos ou técnicos para dar resposta ao crescente número de intervenções que ocorreu na cidade devido a projetos de reabilitação urbana, entre outros. Os trabalhos arqueológicos são maioritariamente promovidos e financiados por particulares (Morán e Parreira, 2009) o que faz com que uma parte significativa dos trabalhos sejam os de acompanhamento, e esse tipo de intervenção requer uma colaboração muito estreita entre os arqueólogos e os restantes responsáveis e intervenientes, sejam os projetistas, os empreiteiros, os serventes ou os técnicos de fiscalização (Madeira, s.d.). Na maioria das vezes a tensão entre as partes e a pressão de obra requerem uma especial inteligência na gestão e no poder de negociação por parte dos arqueólogos envolvidos (Madeira, s.d.). É indiscutível que em Lagos domina a Arqueologia preventiva, que pode ser encarada como uma variante da Arqueologia urbana, havendo essencial- 
mente trabalhos de prospeção, sondagem e acompanhamento (Gráfico 2.). Mas existem também casos em que pelo valor e promessa dos vestígios encontrados as ações de prevenção deram lugar a projetos de investigação, como é o caso de Monte Molião.

No centro histórico de Lagos, as intervenções executadas ao longo dos últimos anos permitiram uma avaliação de risco dos vestígios preservados no subsolo urbano, cujos dados foram usados para criar a Carta de Risco com índices diferenciados de potencialidade (Morán e Parreira, 2009). O mapeamento de gradientes de sensibilidade arqueológica permite justificar uma normativa de medidas de salvaguarda e/ou valorização, condicionantes dos projetos de construção, sejam de iniciativa publica ou privada, como o acompanhamento arqueológico de desaterros e/ou demolições, o exame parietal para salvaguardar possíveis preexistências no cerne das construções, as escavações de diagnostico, escavações em área e ausência de medidas preventivas de impacte sobre o património arqueológico enterrado (Morán e Parreira, 2009).

A adopção de procedimentos de salvaguarda diferenciados por gradientes de sensibilidade, permitiu adotar um normativo que se concretizou no artigo $19^{\circ}$. Do Regulamento do PUMP e se ambiciona vir a plasmar nos Regulamento do PU e PP de lagos (Morán e Parreira, 2009). o que se sucedeu com a revisão do PDM feita em 2015.

\section{CONCLUSÕES}

Parece-me necessário começar por realçar o facto de que neste trabalho foram usados os dados disponíveis no Portal do Arqueólogo, que, como é já de conhecimento geral, não se encontra atualizado. Para além de que na cidade de Lagos existem alguns sítios intervencionadas em contextos de Arqueologia preventiva aos quais não foi atribuído CNS e que portanto não se incluem nos trabalhos aqui contabilizados mas que merecem uma referência, uma vez que sítios como o Cemitério de Escravos ou a fábrica de preparados de peixe da Rua Silva Lopes resultaram na produção de conhecimento científico através da publicação de artigos e de conferências e contribuíram para o conhecimento de períodos e aspetos concretos da história da cidade. Sítios que se não fosse pela legislação atual, estariam perdidos e destruídos.

É defendido desde o início que a Arqueologia urba- na deve construir um projecto específico para cada cidade, mas isso não implica necessariamente que tenha que ser sempre a mesma equipa em campo, apenas que quem está em campo cumpra as mesmas regras e procedimentos e que todos os trabalhos estejam coordenados entre si, sendo para tal necessário que haja um núcleo central responsável pela coordenação e pelo cumprimento dos mesmos procedimentos. O que permite que a cidade tenha um projecto específico e uma direcçao única, ainda que coletiva e dinâmica (Lemos,2006).

Embora sejam sempre discutidas as faltas cometidas pelos promotores, a sua falta de cooperação, etc... não pode ser ignorado o facto de que por vezes a falta de qualificação técnica das equipas de Arqueologia contratadas diretamente pelos empreiteiros, ou o interesse vincadamente comercial de algumas empresas de Arqueologia, pode colocar em risco não só a salvaguarda patrimonial como desajustar o financiamento previsto (Morán e Parreira, 2009). Pelo que a existência deste núcleo central para coordenar, guiar e em ultima instancia avaliar as equipas, ou mesmo no lugar de ser dada ao promotor a escolha da equipa de Arqueologia a contratar que seja este grupo central a dar uma lista de equipas que a seu ver estejam equipadas com as técnicas e conhecimentos necessários à atuação no meio urbano e a cidade em causa, em concreto.

No que há divulgação científica respeita, fica claro que há uma dispersão dos conhecimentos, apesar do aumento do número de trabalhos, para além de que as autarquias terem tendência a privilegiar a divulgação dos resultados locais, como processo identitário e diferenciador.

A situação atual de trabalho não é de todo favorável à produção de conhecimento, tendo em conta que acuam em campo essencialmente equipas de empresas de Arqueologia que assim que terminam um trabalho estão a partir para o próximo, pois o ritmo de avanço e de reabilitação urbana está ao rubro, especialmente em locais como Lagos que são estâncias balneares e consequentemente sítios de eleição para o turismo, e que raramente os cadernos de encargos contemplam o estudo e publicação. Panorama que na minha opinião veria pelo menos parte dos seus problemas solucionados pela existência destes núcleos centrais aptos a coordenar e a processar os dados obtidos em campo, por forma a produzir uma imagem coerente da história da cidade, e responsável pelo retorno deste conhecimento à população. 
Penso que seja ainda relevante comentar que ao realizar este trabalho se tornou evidente que as questões levantadas por vários autores há dez anos atrás quando às Arqueologias Urbana e Preventiva, qual o seu papel e como melhor as gerir, se mantém as mesmas. O que é um indicador de que alguns problemas primários destes ramos permanecem sem solução.

\section{BIBLIOGRAFIA}

BARBOSA, P. G. (1993) - O porto de Lagos no final da Idade Média: algumas reflexões. Cadernos Históricos. IV, pp. 15-26.

Biddle, M. (1974) - The Future of the Urban Past, in Rathtz, P. (ed), Rescue Archaology, Harmonds-worth: 95-112.

Biddle, M. e Hudson, M. D. (1973) - The future of London's Past. A survey of the archaeological implications of planning and development in the nation's capital, Londres.

BLOT, Maria Luísa Pinheiro (2003) - Os portos na origem dos centros urbanos. Lisboa: Instituto Português de Arqueologia.

COUTINHO, Valdemar (2001) - Dinâmica defensiva da Costa do Algarve do Período Islâmico ao século XVIII. Portimão: Instituto de Cultura Ibero Atlântica.

DELGADO, M.; MARTINS, M.; LEMOS, F. S. (1989) Dossier - Salvamento de Bracara Augusta. Fórum 6, Braga. p.3-39.Disponívelem:http://repositorium.sdum.uminho. pt/handle/1822/13335

DÍAZ-GUARDAMINO, M.; MORÁN, E.; FILIPE, I. (2006) - Intervenção arqueológica no Largo de Santa Maria da Graça e a sua área envolvente (Centro Histórico de Lagos): A igreja, o cemitério e a muralha junto à Porta da Vila. Xelb, Silves, 6 [Actas do 30 Encontro de Arqueologia do Algarve. Silves, 20 a 22 de Outubro de 2005]: pp. 111-124.

FRAGAS, T. M. (2013) - Projecto de Carta Arqueologica do Concelho de Lagos (2006-2010): Historia e Desenvolvimentos. ARNAUD; J. M.; MARTINS, A.; NEVES, C. (coords.) Arqueologia em Portugal: 150 anos. Associação dos Arqueólogos Portugueses. Lisboa. pp. 1207-1212.

LEMOS, F. S. (2002) - Arqueologia Urbana em Portugal: a cidade, o poder e o conhecimento. Arqueologia e História. Vol. 54, Associação dos Arqueólogos Portugueses. Lisboa, pp. $245-253$.

LEMOS, F. S. (2006) - A lei e Arqueologia urbana. Praxis Archaeologica. 1, pp. 15-21.

LEMOS, F. S.; MARTINS, M. (1992) - A Arqueologia Urbana em Portugal. Penélope. Fazer e Desfazer a História. N. 7 , pp. 93-103. Disponível em: https://www.researchgate.net/ publication/28224506_A_Arqueologia_Urbana_em_Portugal

MADEIRA, S. (s.d.) - Arqueologia Urbana, subsídios para a sua compreensão. Disponível em https://www.cm-coimbra.pt/index.php/areas-de-intervencao/urbanismo/ gabinete-para-o-centro-historico/grupo-de-arquelogia/ item/1852-investigacao

MADEIRA, S. P. F. (2011) - O Museum of London e a Arqueologia Urbana, um exemplo de gestão arqueológica do espaço urbano e a sua possível aplicação ao território português. Coimbra: [s.n.], 2011. Tese de Mestrado apresentada à Faculdade de Letras da Universidade de Coimbra, orientada por Pedro Carvalho.

MARTINS, M; RIBEIRO, M. C. (2009/2010) - A Arqueologia urbana e a defesa do património das cidades. Fórum 44-45, Braga. pp. 149-177. Disponível em: https://www. google.pt/url?sa $=t \& r c t=j \& q=\&$ esrc $=s \&$ source $=w e b \& c d=$ $3 \& \mathrm{cad}=$ rja\&uact $=8 \&$ ved $=$ oahUKEwip $3 \mathrm{OHh}_{5}$ JbZAhVBIR QKHeaTDwIQFggzMAI\&url=https\%3A\%2F\%2Frepositori um.sdum.uminho.pt $\% 2$ Fbitstream $\% 2{ }_{21} 1822 \% 2 \mathrm{~F}_{1} 3351 \% 2 \mathrm{~F}_{1} \%$ 2FFourm\%252044-45.pdf\& usg=AOvVaw3fvIqu2BdLl7CT hAP7PUKC

MORÁN, E. (2006) - Arqueologia urbana no centro histórico de Lagos: Estratégia de intervenção e balanço dos resultados obtidos. Xelb.6, pp. 103 -110.

PARREIRA, R. (1997) - O salvamento arqueológico das ruínas romanas da Praia da Luz (Lagos): As oficinas de salga a oriente do balneário (escavações de 1987-88). Setúbal Arqueológica, Setúbal, 11-12, pp. 241-248.

PAULA, R. M. (1992) - Lagos, Evolução Urbana e Património. Lagos: Câmara Municipal de Lagos.

RODRIGUEZ TEMINO, I. R. (2004) - Arqueologia urbana en Espana. Barcelona: Ariel Patrimonio.

VEIGA, S. P. M.E. DA (1910) - Antiguidades monumentaes do Algarve: Capítulo V: Tempos históricos. O Archeologo Português, Lisboa, XV, pp. 209-233.

VEIGA, S. P. M. E. DA (2006) - Antiguidades Monumentais do Algarve, V: Tempos Históricos. Silves: Câmara Municipal de Silves / Museu Nacional de Arqueologia. 


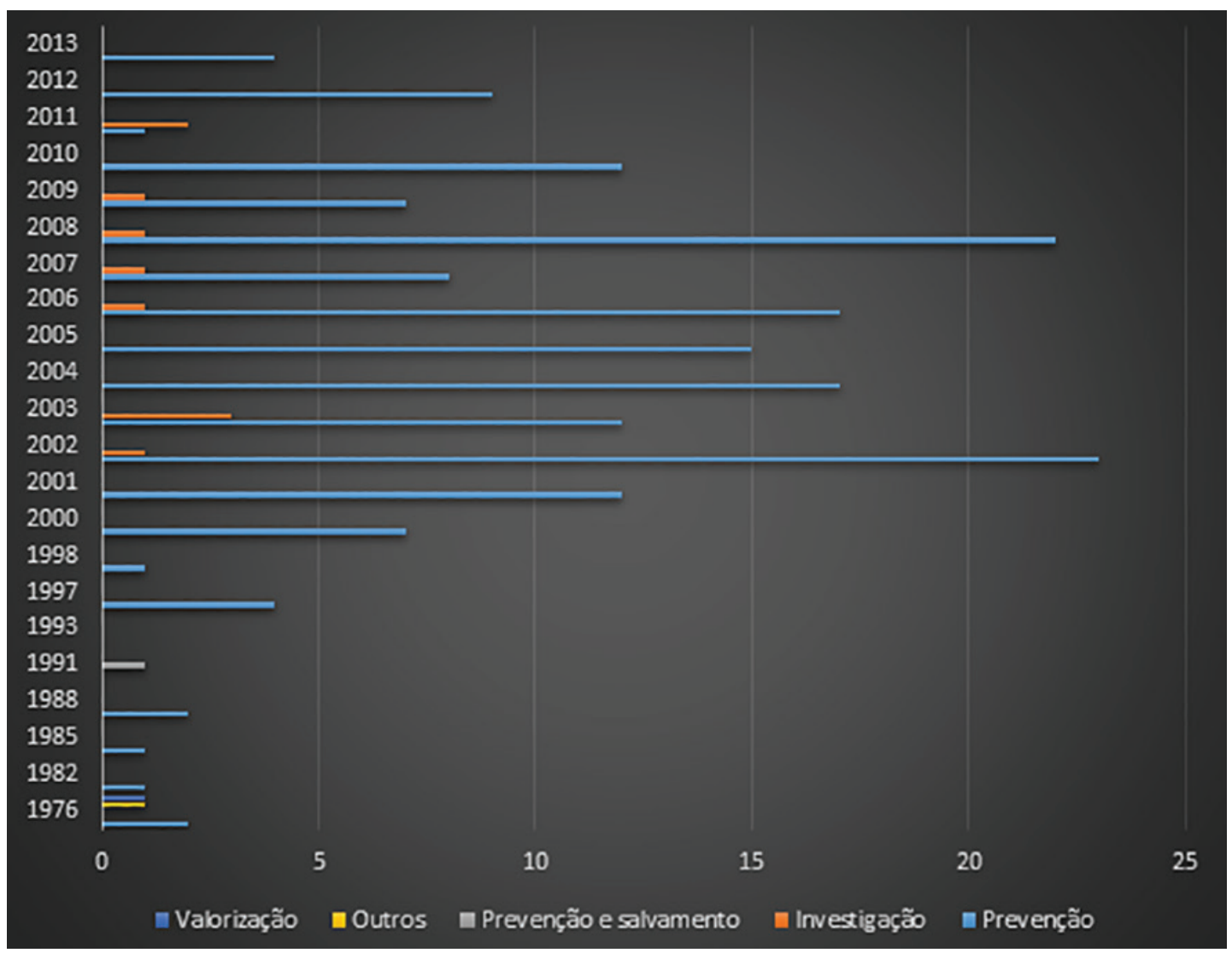

Gráfico 1 - Distribuição das categorias de trabalho por ano.

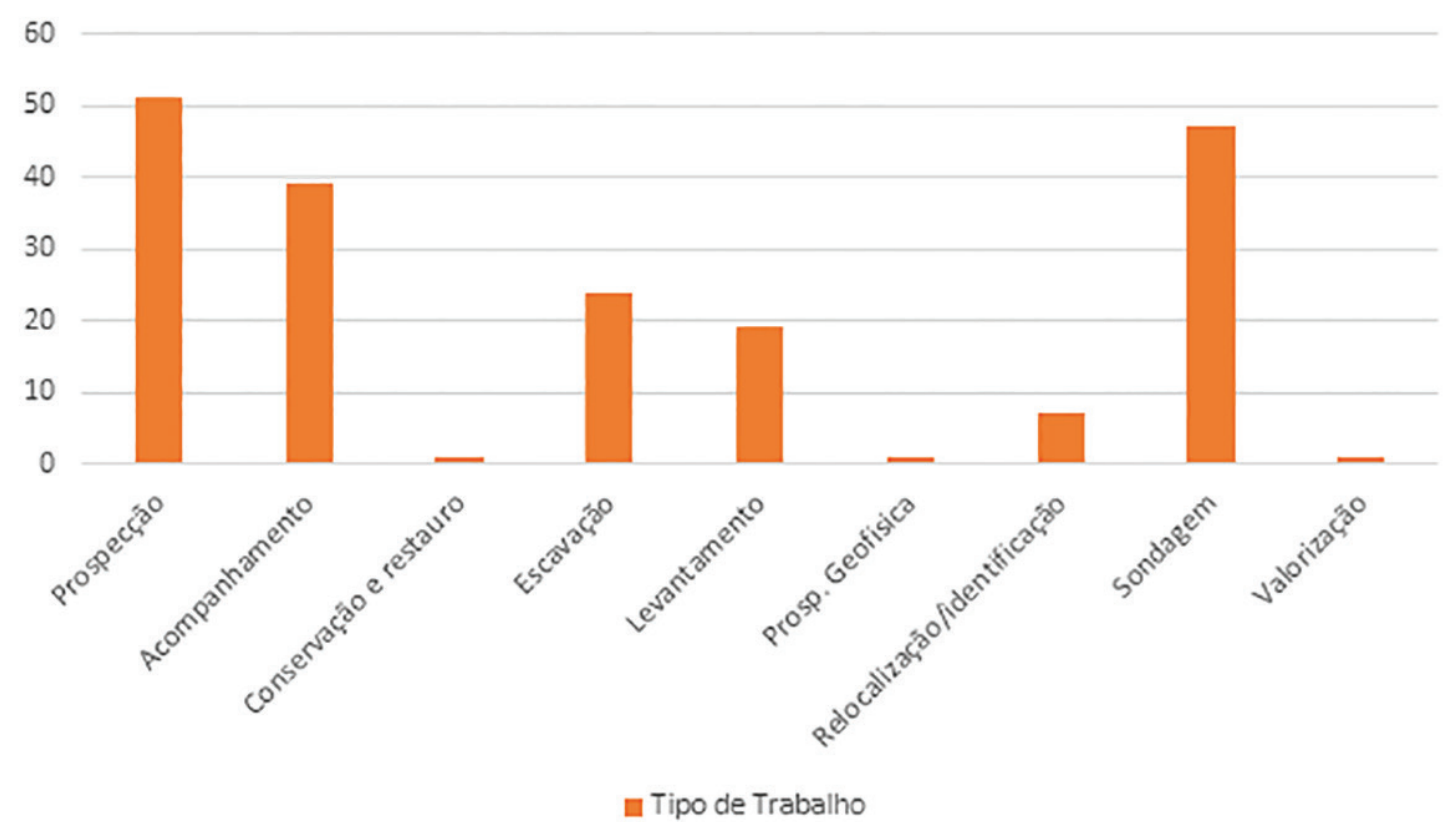

Gráfico 2- Quantificação dos tipos de trabalho. 


\begin{tabular}{|c|c|c|c|c|c|c|c|c|c|c|c|c|c|c|c|c|c|c|c|c|c|c|}
\hline $\begin{array}{l}\text { Ano } \\
\text { de Traballo }\end{array}$ & $\stackrel{\circ}{5}$ & $\ddot{\mathscr{\&}}$ & $\dddot{\&}$ & $\stackrel{\infty}{\mathscr{\&}}$ & $\Phi$ & 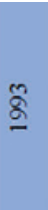 & 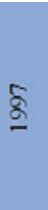 & $\stackrel{\infty}{\Sigma}$ & 8 & $\overline{8}$ & శ్ & $\tilde{8}$ & ¿্ণ & ๕్ & 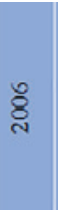 & 8 & 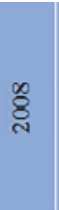 & \&े & $\frac{\mathrm{N}}{\sqrt{2}}$ & $\bar{c}$ & 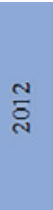 & $\frac{m}{\infty}$ \\
\hline Prevenção & 2 & 1 & 1 & 2 & & & 4 & 1 & 7 & 12 & 23 & 12 & 17 & 15 & 17 & 8 & 22 & 7 & 12 & 1 & 9 & 4 \\
\hline Investigação & & & & & & & & & & & 1 & 3 & & & 1 & 1 & 1 & 1 & & 2 & & \\
\hline $\begin{array}{l}\text { Prevenção e } \\
\text { salvamento }\end{array}$ & & & & & 1 & & & & & & & & & & & & & & & & & \\
\hline Outros & & & & & & 1 & & & & & & & & & & & & & & & & \\
\hline Valorização & & & & & & & & & & & & 1 & & & & & & & & & & \\
\hline Prospeção & 2 & & & 2 & & 1 & & & & 3 & 1 & 6 & 9 & & 3 & & 15 & & 3 & 1 & 5 & \\
\hline Acompanhamento & & & & & & & & & & & 5 & 2 & 5 & 4 & 7 & 6 & 3 & 3 & 3 & & 1 & \\
\hline Conservação e restauro & & & & & & & & & & & 1 & & & & & & & & & & & \\
\hline Escavação & & 1 & 1 & & & & 4 & & & 4 & 5 & 1 & 1 & & 1 & 1 & 1 & 1 & 2 & 1 & & \\
\hline Levantamento & & & & & 1 & & & & 6 & 3 & 5 & & 2 & 2 & & & & & & & & \\
\hline Prosp. Geofisica & & & & & & & & & & & & & & 1 & & & & & & & & \\
\hline $\begin{array}{c}\text { Relocalização/identific } \\
\text { ação }\end{array}$ & & & & & & & & & & & 2 & 1 & & & & & & & & & & 4 \\
\hline Sondagem & & & & & & & & 1 & 1 & 2 & 5 & 5 & & 8 & 7 & 2 & 4 & 4 & 4 & 1 & 3 & \\
\hline Valorização & & & & & & & & & & & & 1 & & & & & & & & & & \\
\hline
\end{tabular}

Tabela 1 - Distribuição dos trabalhos arqueológicos realizados na área urbana de Lagos entre 1976 e 2013, em categorias e tipos de trabalhos. 



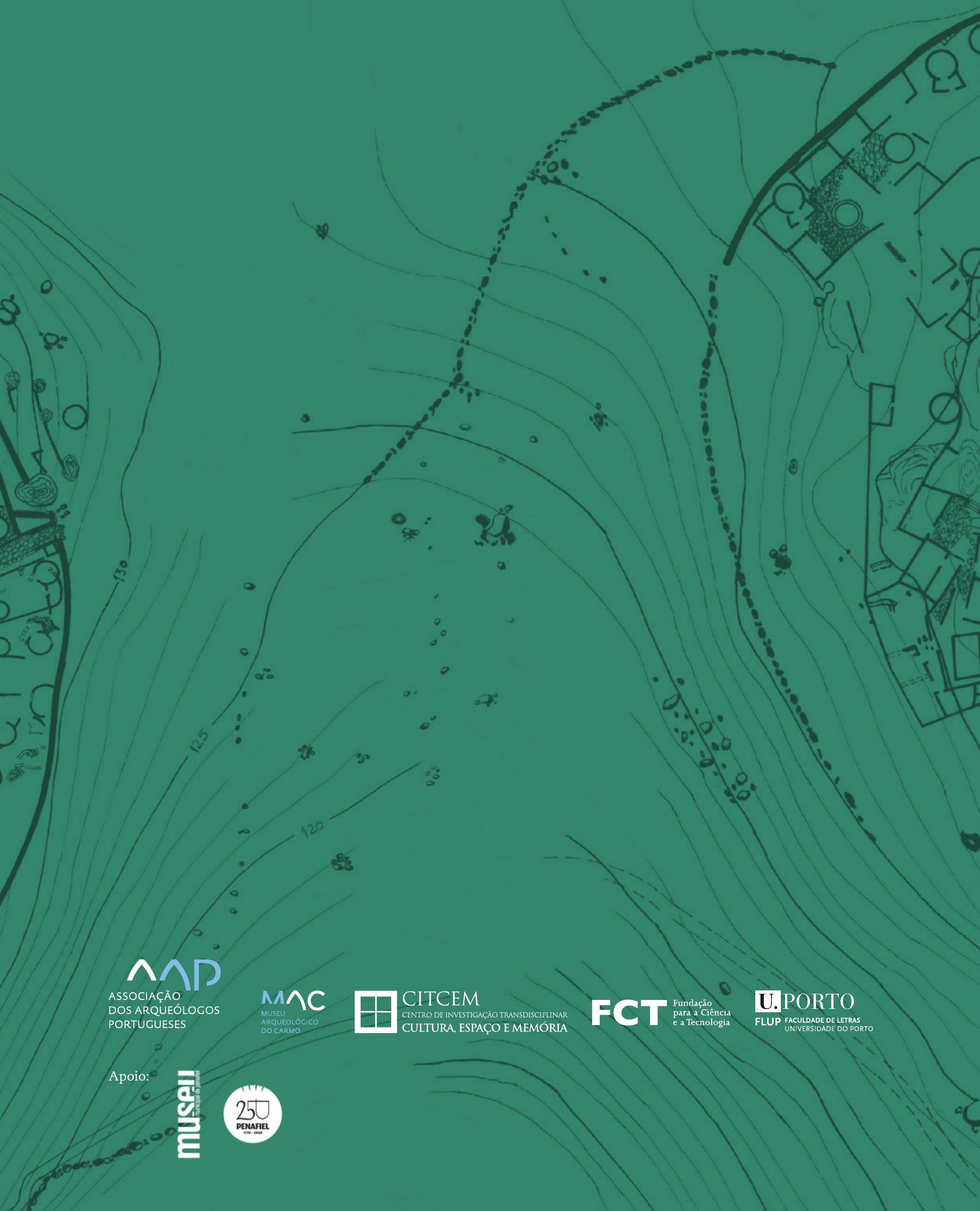

